\title{
Cihannüma
}

Tarih ve Coğrafya Araştırmaları Dergisi

Say1 III/1 - Temmuz 2017, 183-185

\section{Nicolas Monceau, Générations démocrates: Les élites turques et le pouvoir, Paris: Éditions Dalloz, 2007, XVIII+615 shf., ISBN: 9782247076499.}

Burada kısa bir tanıtımı amaçlanan eser, 2016'da kuruluşunun 25. y1lını yaşayan Tarih Vakfı (2005'e kadar 'Türkiye Ekonomik ve Toplumsal Tarih Vakfi') üzerine siyaset bilimi alanında hazırlanıp Grenoble II Üniversitesi'nde 2006'da kabul edilmiş ve bir sene sonra Fransa'da kitaplaştırılmış bir doktora tezidir. Çalışma kitaplaştırılırken tercih edilmiş isim "Demokrat Nesiller: Türk Elitler ve Güç/İktidar", doktora tez başlığ1 ise "Reformcu Elitler Üzerine Siyaset Sosyolojisine Katkı: Türkiye Tarih Vakfı Örneği: Eğitim-Kariyer-Aktivizm Seyirleri, Mobilizasyon, Ülke Meselelerine Dair Tutumlar" (Contribution à une sociologie politique des élites réformatrices: le cas de la Fondation d'bistoire de Turquie: trajectoires, mobilisation, attitudes) şeklinde Türkçede ifade edilebilir. Bordeaux Üniversitesi'nde siyaset bilimi sahasında öğretim üyesi olarak kariyerine devam eden eser sahibi Nicolas Monceau, Fransız Anadolu Araştırmaları Enstitüsü'nde araştırmacı, Galatasaray Üniversitesi ile Marmara Üniversitesi'nde misafir öğretim elemanı olarak bulunmuş, çalışmasını sahada altı yıl geçirerek gerçekleştirmiştir.

Giriş, sonuç, ekler, kaynakça, indeks vs. kısımlar dışında, çalışma sekiz bölümden oluşmaktadır: 1) 1960’ların Siyasi Nesline Mensup Oluş, 2) Eğitim Seyirleri, 3) Mesleki Seyirler, 4) Aktivizm Seyirleri, 5) Bir Kurum Olarak Tarih Vakfi, 6) Tarihi Yeniden Yazmak: Tarih Vakfı Faaliyetlerinin Siyasi Yönü, 7) Avrupa'ya Dair Tutumlar, 8) Demokrasiye Dair Tutumlar. Giriş kısmında, yaygın görüşe göre siyaset sosyolojisinin alt disiplini olarak kabul edilen elit sosyolojisine dair teori, yaklaşım ve kavramsal çerçeveler, Karl Mannheim'ın metinlerine özel vurgu yapilarak sunulmaktadir. Siyasi ve entelektüel elit anlaminda 'nesil'in tanımlanması ve tahlili hususunda Monceau, Mannheim'ı esas almaktadır. Bir tarih çalışması olmamasına rağmen bu kısımda Marc Bloch'a da refere edildiği özellikle zikredilmelidir. Bloch'un salt yaş aralıklarını temel almayan, 'uzun zaman diliminde nesil/kisa zaman diliminde nesil' (générations courtes/générations longues) olarak tercüme edilebilecek kavramsal ayrımından bahsedilmektedir. Nitekim Monceau çalışmasının çeşitli yerlerinde, Bloch'un kurucularından olduğu Annales okulunun temel kavramlarından longue durééyi de (örneğin kırk yılı aşkın bir süreden bahsederken) kullanmaktadır. Bu kabul, kurum olarak 1991-2005 dönemi ele alınan tarih odaklı bir sivil toplum kuruluşu olan Tarih Vakfı mensuplarının, 27 Mayıs 1960 askeri müdahalesi sonrası ortamda vücuda gelmiş bir siyasi-entelektüel elit nesil olduğu ana argümanını desteklemekte yararlı olmaktadır. Nitekim ilk dört bölüm, çok kabaca ifade etmek gerekirse her şeyden önce bu ana argümanı oldukça detaylı bir şekilde ortaya koymaktadır: Buna göre Tarih Vakfı mensupları doğum y1lları, ailelerinden aldıkları kültürel sermaye, eğitimleri, kariyerleri-meslekleri, entelektüel ve siyasi görüşleri-faaliyetleri, askeri müdahalelerden etkilenmeleriaskeri müdahaleleri algılayışları başta olmak üzere birçok değişken göz önünde bulundurulduğunda belirli bir homojenlik arz eden siyasi-entelektüel bir elit 
gruptur. Beşinci ve altıncı bölümler kuruluş süreci, finansal yapı, devletle ve özel sektörle ilişkiler, medyada yer alış, faaliyetler, (Ermeni meselesi, tarih ders kitapları başta olmak üzere) tartışmalı yakın tarih konularında tutumlar gibi konuları ele alan kurum tarihidir. Son iki bölüm ise Monceau'nun çalışmasını yaptığı ve yayınladığ1 yılların gündemini hem içerik hem üslup itibariyle tam anlamıyla yansıtacak şekilde Türkiye'nin AB'ye kattlımı ve bu bağlamdaki meseleleri ('insan hakları', 'demokratikleşme' vs.) Tarih Vakfı mensuplarının tutumlarını merkeze koyarak (Türkiye ve Avrupa kamuoyu tutumlarına da yer vererek) irdelemektedir. Monceau, Avrupa ve demokrasi yanlısı elitler olarak nitelendirdiği grubun AB’nin gelecekteki olası partnerleri olmaları nedeniyle derinlemesine etüt edildiğini belirtilmektedir. Zira Avrupa'ya entegrasyon süreci bağlamında Türkiye'nin dönüşüm dinamiklerini ve süreçlerini daha iyi anlamak için bu reform hareketine katılan Türk elitlerini bilmek olmazsa olmazdır.

Yayımlanmış kitaplar, süreli yayınlar, basın tarama dosyaları, broşürler, kataloglar, faaliyet tanıtım ilanları gibi böylesi bir çalışma için standart olarak nitelendirilebilecek yazılı kaynaklar haricinde Tarih Vakfı Bilgi-Belge Merkezi başta olmak üzere özel kurum arşivlerine ve şahıs arşivlerine (özellikle Aziz Nesin ve Orhan Silier) ait evrak kullanılmıştır. Söz konusu şahıs arşivlerinde daha önce bir araştırma kapsamında kullanılmamış çok sayıda yazışma ve notlardan faydalanılmıştır. Tarih Vakfi'nın birçok mensubunun aktif olarak yer aldığı Türkiye İşçi Partisi’ne ait evrak ve kurumun önemli isimlerinden Silier’in özellikle 12 Eylül sonrası Avrupa yıllarındaki faaliyetlerine dair belgelerin öneminin altı çizilmelidir. Yönetimin izniyle Tarih Vakfi'nın finansal ve iç strateji raporları, veritabanları da araştırma kapsamında kullanılmıştır. Katıllımcı gözlemci olarak Monceau'nun kurumdaki toplantı ve faaliyetlerine dair notları da altı çizilmesi gereken kaynaklardandır. Grubun aktivizm geçmişlerine dair yazılı kaynak çok az olduğu için mülakat ve anketler ayrı bir değer arz etmektedir. Monceau, anket ve mülakatlar sayesinde dikkat çekici bir hassasiyette nicel ve nitel analiz yapabilme imkânı bulmuştur.

Cumhuriyet devrinde tarih disiplininin gelişiminde şimdiden önemli bir kurumsal aktör olarak yerini almıs olan Tarih Vakfi 'elit'iyle ilgili çalışmanın ilk dört bölümünde Monceau'nun çok sayıdaki tespit ve değerlendirmesinden birkaçına burada değinmenin anlamlı olacağı söylenebilir. Monceau'nun ilk olarak belirttiği husus, grubun cinsiyet dağllımı itibariyle erkek ağırlıklı oluşudur. 2000 yllından itibaren kadın oranında artış görülmesine rağmen çalışma sonlandırıldığında bu tablo değişmemiştir. İkinci husus, söz konusu 'elit' mensuplarının doğum yerlerinin İstanbul, Ankara, İzmir başta olmak üzere Türkiye'nin batısında yer alan büyük şehirler olduğu, dolayssıyla kentli bir grup söz konusu olduğudur. Bu tablo, çalışmanın yapıldığı esnada ikamet yerlerinin dağılımında da karşımıza çıkmaktadır. Tarih Vakfı mensuplarının ebeveynlerinin meslek dağıllımlanı da kentli oluşu destekler yöndedir. Tarih Vakfı yönetici grubunun çoğunluğunun Türkiye'de bir Batı dilinde eğitim veren lise ve/veya üniversiteden mezun olduğu da Monceau tarafindan tespit edilmiştir. Gerek tüm mensuplar, gerekse de yönetici kesim için 
ögretim dili İngilizce olan bir Türk üniversitesinden mezun olma oranı da dikkat çekici bir seviyededir. Tarih Vakfı mensupları arasında lisans veya lisansüstü seviyesinde tarih alanında herhangi bir dereceye sahip kişiler azınlıktadır; bu nedenle çalışma kapsamında yapılan mülakatlar ortaya koymaktadır ki kamuoyunca tanınan birçok tarihçi kendisini 'alaylı tarihçi' olarak nitelemektedir. Monceau, lisans veya lisansüstü seviyesinde tarih disiplinini tercih etmeme hususunda dönemin Türkiye'sinde bu imkânın çok az üniversitede oluşu ve bu tercihin mesleki anlamda cazip olmama noktalarına değinmektedir. Başka disiplinlerden tarihe 'alaylı' dâhil olma konusunda ise başlıca motivasyonun 'az gelişmişlik', 'Asya tipi üretim tarzı' gibi dönemin düşün hayatına hâkim yoğun ve heyecan verici tartısmalar ile özellikle sol fikir çevrelerinin bu disipline verdiği önemden kaynaklandığı ifade edilmektedir. İncelenen grupta, Batı'da çoğunlukla en üst seviyede kabul edilen bir akademik kurumda yüksek öğrenim görmüş olma oranının da dikkat çekici bir seviyede olduğu belirtilmelidir. Bu durum uluslararası bir entelektüel çevreye dâhil olma, yabancı dil bilgisi edinme, Batı'daki akademik üretimin Türkçeye çevirisinde ciddi rol oynama imkânlarını sağlamışır. İncelenen grubun özellikle 1960-80 döneminde parti, sendika, öğrenci örgütleri faaliyetleri, takip ettikleri yayınlar, katkıda bulundukları yayınlar ve benzeri değişkenler, sol mensubiyeti net bir şekilde ortaya koymaktadır. Grup üyelerinin askeri müdahaleleri algılayışları ve bu müdahalelerden meslek-kariyer anlamında (1971 ve 1980'den olumsuz olarak) etkilenmelerine değin tespitler de siyaseten solda konumlanışı desteklemektedir. 1960, 1971, 1980 ve 1997 askeri müdahaleleri içinde Monceau'nun tespitine göre bu elit 'nesil'in vücuda gelmesinde 'kurucu olay' olan 27 Mayıs'in grup nezdinde sonuçları itibariyle olumlu olarak değerlendirilen tek müdahale olduğu ortaya konmuştur. Ayrıca grubun net bir şekilde laiklik yanlısı olduğu tespitine de vurgu yapilmalıdır.

II. Dünya Savaşı sonrası Türkiye'sinde entelektüel hayat ve tarih disiplini hakkında dikkat çeken bu hacimli ve detaylı eserin Türkçeye kazandırılması umulur.

\section{Yasin Özdemir*}

* Arş. Gör., İzmir Kâtip Celebi Üniversitesi Sosyal ve Beşeri Bilimler Fakültesi Tarih Bölümü, 35620, Balatçı, Çiğli - İzmir / Türkiye, yasin135@yahoo.com 

